\title{
Islamic Education Based on Arabic Pegon Letters in Madrasah Diniyah Al Barokah Watuagung Tambak Banyumas
}

\author{
Mohammad 'Ulyan'1*, Nurti Budiyanti2', Shepta Adi Nugraha ${ }^{3}$ \\ ${ }^{1}$ Institut Tekhnologi Telkom Purwokerto, Indonesia \\ 2 Universitas Pendidikan Indonesia, Indonesia \\ ${ }^{3}$ Institut Agama Islam Negeri Salatiga, Indonesia
}

Corresponding Author: Mohammad Ulyan, ulyan@ittelkom-pwt.ac.id*

\begin{tabular}{|c|c|}
\hline \multirow{11}{*}{$\begin{array}{l}\text { ARTICLE INFO } \\
\text { Article history: } \\
\text { Received } \\
\text { October 29, } 2019 \\
\text { Revised } \\
\text { May 03, } 2020 \\
\text { Accepted } \\
\text { June 07, } 2020\end{array}$} & ABSTRACT \\
\hline & This article aimed to analyze the Islamic education based on Pegon \\
\hline & Arabic letters in Madrasah Diniyah Al-Barokah Watuagung. This \\
\hline & research was qualitative research. Observation, interview and \\
\hline & documentation were collecting data of research. The participants consist \\
\hline & of 30 students and 5 teachers as research sample. The results showed that \\
\hline & Madrasah Diniyah Al-Barokah used the Arabic letters Pegon in learning. \\
\hline & This Madrasah still exists amid the vortex of globalization to preserve the \\
\hline & legacy of civilization for superior Islamic education. The curriculum was \\
\hline & taught in the form of Fikih, Morals, Aqidah, Tajwed, Al-Quran, Nahwu and \\
\hline & $\begin{array}{l}\text { Sharaf. Islamic education was taught by teachers who are graduates of } \\
\text { various Pesantren at Java, hence they were scientifically and experienced. }\end{array}$ \\
\hline & Keywords: Islamic Education, Arabic Pegon, Pegon Letters \\
\hline How to cite & $\begin{array}{l}\text { 'Ulyan, M., Budiyanti, N., \& Nugraha, S. (2020). Islamic Education Based on } \\
\text { Arabic Pegon Letters in Madrasah Diniyah Al Barokah Watuagung Tambak }\end{array}$ \\
\hline & $\begin{array}{l}\text { Banyumas. Jurnal Iqra' : Kajian Ilmu Pendidikan, 5(1). 133-144. } \\
\text { https://doi.org/10.25217/ji.v5i1.576 }\end{array}$ \\
\hline Journal Homepage & http://journal.iaimnumetrolampung.ac.id/index.php/ji/ \\
\hline This is an open acce & icle under the CC BY SA license \\
\hline & https://creativecommons.org/licenses/by-sa/4.0/ \\
\hline Published by & Institut Agama Islam Ma'arif NU (IAIMNU) Metro Lampung \\
\hline
\end{tabular}

\section{INTRODUCTION}

Cultural values have benefits that are sometimes prone to neglect. Local Wisdom is regarded as antiquated and outdated so it must be abandoned. The people prefer to pursue modernity with all the technological advances without seeing the negative consequences. Many common assumptions think that only modernity can advance human life in all areas.

The pattern of community learning in studying religion has changed. Many people who only focus on the development of technology in seeking religious knowledge. It can be proven from most of people used internet media as the first source in learning, speedily a new 'culture' of Indonesian society (Affan, M., \& Thohir, A, 2020; Aguilar, G. K., et al., 2017). Modern times offer ease in many aspects of life. Everything is instant and practical. However, not all of the instant things have a good effect to digest by the minds of everyone.

Misunderstanding in comprehending Islamic religious teachings causes various social problems up to the criminal. Misinterpretation of religious teachings is compounded by various political interests, economic gaps, and the 
end to undermine the social order of the nation and state (McClure, P. K, 2017; Alimi, 2019). Religious teachings are presented to the foundation of the state, the government, and even the military. This pattern of collision is nothing other than that of an invader who is often referred to the divide at Impera (politik adu domba). If "sheep" in ancient times such as a tribes' furry, races and languages, now religions' furry.

Globalization eliminates geographic partition. Hence, to get a variety of information access are easily and quickly (Wahyudi, 2017). The acceleration of information flows as a logical consequence of the wave of globalization brings significant changes in society (Chase-Dunn, \& Lerro, 2016), either on the outer structure level (patterns of behavior and attitude) or the inner structures (system values, views of life, philosophy and beliefs) (Kitamura, \& Takahashi, 2020). The changing occur due to cultural contacts between countries that are interpreted as dialectics of new values with old values that dominate each other, allowing homogenization and neoliberalization in all aspects of life including local cultural values that have become Community guidelines (Payne, M., \& Askeland, ,2016; Suradi, 2018).

Need strengthening and devolution of local cultural values with intensively for the younger generation (Suradi, 2018). Islamic education must equip students with 'immunity' so as not to be easily contaminated by the extreme or radicalism. One of the proven alternatives to the success of bridging the great civilization between Islam, Arab and Nusantara are Arabic-Pegon. Pegon manuscript was found since the era of Islamic kingdom in Nusantara (Yakin, 2016). Because Indonesia becomes an important fragment in the history and dynamics of Islamic civilization development (Hizbullah, et al., 2019). These Arabic-pegon letters in turn give understanding easily, friendly with maintaining a cultural identity. Arab-Pegon can be a solution in Islamic education in order to give a good understanding morality and culture. Hence, It is necessary to do more research in relation to the education-based letter Pegon.

Some previous studies, Pudjiastuti (2009) only discussed the history of Pegon in Java. The aim of using the Pegon Arabs to the spread of Islam, but in the end it also serves as a writing media with various purposes such as literature text, documents, letters and others. While, the Research on Sahal \& Halimi (2018) declare the contribution of Arabic Pegon has a noticeable contribution in Arabic language learning in Indonesia. Fikri's research gave the conclusion that Pegon which developed in Java in the 18-19 century has become a symbol of Muslims' resistance, either against Hindu-Buddhist beliefs, colonialism, or Puritanism (Fikri, 2014). Moreover, Arabic religious manuscripts in the southern part of Java are mostly in the form of the Arabic Pegon. This research was focused on discussing about the history and the role of Pegon Arabic. Other research inclined to measure the level of understanding on Pegon's writing for students (Bukhory, 2015). Meanwhile, Abdul Munip concluded that the rise of Latin, Bahasa Indonesia and formal Madrasah also contributed to the decline of the Arabic Pegon lately (Munip, 2016). Fadhilah Hasanah also discussed the learning problems of Pegon's Arab writing in Lebak 
Banten, was more about the learning problem of writing Arabic Pegon (Hasanah, 2016).

The decrasion of popularity Pegon letters as Islamic reference was caused replacing by Latin letters with Bahasa Indonesia (Fikri, 2014). Research on Moh Rosyid mentioned that the book nguri-uri Pegon basically preserve the work of the ancestors who spread the attitude of nationalism against colonialism to be inherited amid the glamorism of the millennial World (Rosyid, 2019). Religious education should be an anticipatory solution that should have local wisdom to maintain the identity of a Muslim as well as a citizen (Suradi, 2017). To overcome those problem were necessary to revitalize the element of education that has to be better (Aisyiah, 2016). The religious education is expected to fill the moral and spiritual vacant as one of capital factor to overcome various challenges (Lubis \& Anggraeni, 2018). Madrasah Diniyah Al-Barokah is one of the non-formal educational institutions that implement Pegon as an introduction in learning. The aim of this research was how the implementation of Islamic education based on Pegon in Madrasah Diniyah Al-Barokah.

\section{METHODS}

This research used qualitative method. It was a scientific way to get data with specific objectives and certain usability (Siyoto \& Sodik, 2015). The method of this study used descriptive analysis. It is a method that describes the object analyzed or samples that have been collected, then making conclusions (O'Dwyer \& Bernauer, 2013; Loeb et al., 2017). In other words, the descriptiveanalytical method focuses on the problems found in the field of study (Moser \& Korstjens, 2018).

In collecting data used observation, documentation and interview. In this study were not poured out in the form and number of statistics. The researchers had done observation by using the observation form. Observation activities carried out by observing all activities of students. Observation is done by means of writers coming directly to the research site. The author performs observations to obtain the data related to the learning activities, the neighborhood of Madrasah Diniyah, especially related to Islamic education based on the Arabic letter Pegon.

The Author conducted some interviews with the Ustadz, Ustadzah and students Madrasah Diniyah Al-Barokah. The researchers used deep interview type with the participants who have determined as a sample of the research data. It consists of 30 students as research sample and 5 teachers. The selection of deep interview was intended to be naturally based on the thoughts and answers directly from the teacher and students without limiting the choice of answers. Hence, the results obtained were more complex and natural. Interviews are conducted to get data related to the implementation of Pegon's letter-based learning as well as other supporting data.

The documentation is conducted by studying the books of Pegon letter and other documents supporting this research. The researchers decided to analize the books taught in Madrasah Diniyah Al-Barokah as one of the 
methode in this research. The location of this Research is at Madrasah Diniyah Al-Barokah Watuagung village, Tambak District, Banyumas, Central Java (Herlianti, 2014). The Object in this study is the Islamic education based on Pegon Arabic letter (Yusuf, 2016).

Data analysis using the Miles and Huberman analysis techniques which include data reduction, data display, dan conclusion drawing/verification (Siyoto \& Sodik, 2015). The author seeks the necessary data related to Islamic education based on the Pegon letter which includes the curriculum, the implementation of learning and problematic. The collected Data is then grouped according to the purpose of the study. The final stage of the research is the withdrawal of conclusions from research conducted.

\section{THE RESEARCH'S RESULTS AND DISCUSSION}

\section{The Arabic Pegon Letter}

The success of Islamization in Nusantara cannot be dismantled with ArabPegon role. Arabic-Pegon is an Arabic script that is modified to write local language such as Java, Sunda, Madura, and Melayu. The use of the ArabicPegon letter reflects on the affirmation of Javanese cultural identity as well as a cultural strategy against Dutch colonialism who then instructed to use Latin writings in bureaucracy (Mustaqim, 2017). Arab-Pegon helps the public to understand the messages of Islamic religious teachings even if they do not speak the Arabic language (Irfan, 2017).

Arab-Pegon has a strategic role as a medium for the inclusion of crossborder and cross-generation scientists into the archipelago through sorogan dan bandongan tradition in Islamic boarding schools (Munip, 2016). Therefore, it is not excessive if the Arabic letter-Pegon contributes in the role of spread of Islam in Indonesia. The implications were born with Muslim-friendly faces of local culture, peaceful love that accommodated harmony. The selection of languages and characters is not merely a mere technical and pragmatic problem, but more than that, it contains elements of culture, traditions, and social interests that live in the community. It also informs about the diversity of traditions and cultural backgrounds and geographical context in Indonesia. Hence, Islamic values can be understood and impregnated by society widely, although they do not master the Arabic language well (Gusmian, 2015).

In different area conditions and area, many scholars who wrote the book with the Arabic-Pegon letter to greet the audience of Javanese Muslims who are mostly still living in rural areas (Fahmi, 2019). Javanese language has a richer vocabulary than the Indonesian language. Many words in Javanese do not have an equivalent meaning when it translated into Indonesian. The books with the Pegon Arabic script have contributed to the study of Islam in Java. The role rose when the Kyai in Pesantren was supported by book publishing companies and bookstores that culminated in the 1950-an era until the 1980's. The books are widely used in Madrasah Diniyah, Pondok Pesantren and Taklim Assembly (Munip, 2016). The use of Arab-Pegon became an alternative as a means in the historical dynamics of Islamic intellectualism in Nusantara and Java in 
particular. Thanks to this activity, Arabic language discourse is not only enjoyed by the elite of the Kyai-santri only, but also can be read outside the walls of Pesantren. The substance of Pegon's comprehensive Arabic translation in turn leads to the life of Muslims far from the glittering violence and intolerance in the name of religion (Munip, 2016). The Arabic letter Pegon with its specificability, becomes a kind of password that is not easily contamination by various parties who have an interest in Indonesia. Pegon Arabic letters have a uniqueness that has a different platform than the Arabic alphabet in general. The values of local wisdom which became the identity of the nation can be handed down to the future generations as a pride in their own way of being an established life. Pegon's Arabic script serves to greet the readers of the rural Muslims (Rokhmad, 2011).

Madrasah Diniyah Al-Barokah is one of the non-formal Islamic educational institutions located in Watuagung village, Tambak district, Banyumas Regency. This Madrasah is located in a cool and beautiful hilly area. In the afternoon after the children of Kindergarten, Elementary and Junior High School, many people visit this madrasah to gain religious knowledge. Madrasah Diniyah al-Barokah was established in 1997 at Masjid Al-Barokah Watuagung village, Tambak District, Banyumas. The science that has been obtained from boarding school, then practiced in Madrasah Diniyah al-Barokah so that the scientific dynamics become not stagnant and continues to evolve (Ahyadi, 2019). There are eight classes at Madrasah Diniyah Al-Barokah, with the number of 20 students each class so that the total students is around 160 students. The teacher who teaches at the Madrasah is 17 teachers, but who actively teaches is about 10 person (Rohmah, 2019). Madrasah Diniyah alBarokah has positive support from the surrounding formal educational institutions. The average elementary school students who paid in Madrasah Diniyah al-Barokah received a good value especially on Islamic religious education. Families, schools and communities are often known as educational tricenters that contribute to the education process. Therefore, in order not to happen moral decline, Islamic education has a very significant role in each education Center (Ahyadi, 2019). The invention of this study shows that the Islamic education of Pegon is emphasizing on the Islamic teaching aspect of local culture through the letter of Pegon as a science of transmitting media. This can be seen from the learning curriculum: Fiqih, Akhlak, Tajwid, and Qira'ati (Ahyadi, 2019). This Madrasah has an interesting uniqueness, including learning using the book of Pegon java. While other educational institutions are competing to pursue the progress of the times which the impacts are not necessarily all good, Madin al-Barakah chose to preserve the sublime values the combination of the civilization of the Islamic world, Arab and Nusantara.

Pegon's Arabian use is a great choice, especially for people living in the countryside. This option is supported by Samidi research, stating that the use of Pegon script and Javanese language is used to facilitate people to read and understand their contents (Samidi, 2015). The book being taught is called the Speaker as the book of Jawa'an which is written using Pegon Arabic script 
(Salamah, 2019). Santri is led to have the skill to understand the language written in the book. The language used is a subtle language that has begun to be rarely used in the community. Syi'ir is an oral speech with a specific rhythm that contains various teachings. The use of Javanese language is dominant, because it teaches Javanese language as an introduction. This method facilitates students to understand the subject matter submitted by Ustadz/teacher. The age of children to adolescents is a very good time to learn, the proverb reveals the study of small time like carving on the rock that will be ringing until old later

The findings are also relevant to Rahmawati's research which reveals that Syi'iran/Singir was written with no neglect of local culture (Java). The reading by being sung (as a Macapat tradition) becomes interesting because the technique can help students in memorizing and understanding Islamic teachings. This is part of the effort to preach one of them by means of cultural acculturation (Rahmawati, 2015). Santri is equipped to be able to pray according to the ordinances taught by the Ulama. Prayer is the duty of every Muslim to be shown. Besides having the basics about reading the Arabic writing Pegon, students are also equipped with the substance of Figh on the Ordinance of Prayer. Learning through this book creates the specificity that constitutes the identity of the students. The findings are supported by Hayyik's research stating that the learning of the book of Fashalatan affects the knowledge of children especially in praying, the child is able to memorize the reading of prayers in each movement and make the child to pray (Hayyik, 2018).

The study in Fiqh discusses al-Mabadi al-Fiqhiyyah by Shaykh ' Umar ' Abdul Jabbar (Ahyadi, 2019). This book is presented with a question and answer model about Figh. The Questions train students to strengthen critical reasoning by building a high sense of curiosity. The answers to these questions are presented plainly so the students have stability in learning about Fiqh. The material is discussed about Islam, Islamic pillars, ablutions, unclean, prayer times, prayer readings, fasting, and prayers. The findings were strengthened also by Ummu Kulsum which mentions there is a significant link between the study of the Mabadi ' Al-Fiqhiyyah with the understanding of the Ministry of Prayer (Kulsum, 2015).

Akhlaq belongs to the curriculum taught in this Madrasah Diniyah. Akhlaq material is taught by al-Akhlaq Lilbanin by Sheikh Umar bin Ahmad Baraja (Ahyadi, 2019). This book is presented in Arabic letters accompanied by the Arabic meaning Pegon underneath. Akhlaq is not only studied as memorization and information about knowledge, but is immediately applied in learning at Madrasah Diniyah. This is done so that the science does not lose its space. In this book discusses about what must to do by the children, the examples of children with good manner, the examples of children who have poor manner, the examples of obedient children, the adab to God, the adab of the Prophet Muhammad saw, the Adab when at home, the Adab to parents, sibling, friends and neighbors. 
This theme was supported by the research of Faiq Nurul Izzah who stated that the study of al-Akhlaq Lil Banin was relevant for the children aged Madrasah Ibtidaiyah ( Izzah \&Hidayat, 2013). Similar research mentions that the study of al-Akhlaq Lil Banin's book has a positive effect on the morality in everyday life (Karim, 2018). The understanding of the concept of Akhlaq is trained and constructed, directly practiced in daily activities and repeated to ingrained meat and produce amal Saalih (Rosidi, 2019). Fiqh learning is essential to be taught to children. This education can be a solution to moral deterioration from various aspects of life. The advancement of science and technology must be based on the values of Akhlakul Karimah to give direction to the collective welfare. There are specific science that makes us be able to read al-Quran correctly, the science is known as Tajwid Science. The students were taught using the book Hidayat al-Shibyan by Syeikh Sa'id bin Sa'ad Nabhan, a book about the science of Tajwid written in the form of a meaningful poem (Ahyadi,2019). Students learn tajwid from the rulings of the ruling Tanwin and Nun Sukun, the Law of Min and Nun that was asked, Lam Ta'rif, and others. Students were guided by the average teachers from various pesantren in Java. This finding was supported by Akhyar who mentioned that the book of Hidayat al-Sibyan has succeeded in having a great influence on Intellectual view (Mohamad, 2012).

Santri who sits in the upper class is also equipped with the science of Nahwu and Sharaf. On the basic level, the students learn about the Jurumiyyah book by Abu Abdillah Sidi Muhammad bin Daud Ash-Shanhaji. While the Learning for kindergarten age is in the form of memorization of daily prayers, the introduction of Hijaiyah letters, and memorization of short letters. The introduction of Hijaiyah letters is very important as the basis of understanding the Pegon Arabic-based curriculum. Then the student who is in the age of big kindergarten begin to be taught to assemble the letters Hijaiyah. It aims to equip the students to be ready when entering the high class that has begun teaching the Pegon book.

The finding showed that Santri in Madrasah Diniyah al-Barokah has been trained to write Pegon early. Writing Pegon letters has begun to be taught on the small kindergarten age class. They were taught Latin writing to then be copied using the letter Pegon. There is a link between using Arabic and Javanese translations and keeping the authenticity of the language. This indirectly formed the character of Love to Islam as well as love to the results of the culture of the region and the nation. Developing the love to the peculiarities of culture is not enough by teaching the theory and slogan, but there must have the direct action involving the students. Admittedly or not, there is a kind of poisitif relationship between the Qur'an of the Kitab Kuning and the Hubbul Wathan (love of Homeland) (Anis et al., 2016). The Kitab Kuning that is conveyed with the letter Pegon contains the planting of love character high homeland to the students. This makes the students not easily affected by the radical understanding that makes the religion as a hammer to hit the integrity of the 
country. Santri has a firm grip on its own belief without disturbing the beliefs of others.

These findings different from previous research because researchers emphasize the Pegon letter applied to Islamic education aspects in Madrasah Diniyah Al-Barokah, while research (Ningsih, 2017; Mahfudz et al, 2018; Hizbullah, 2019; Rokhmad, 2011; Murtadlo, 2014; Bukhory, 2015; Inayatusshalihah, 2017) focuses on the aspects of the language structure as a medium used in Pegon script. In addition, the direction of this research is more inclined to the scientific field of Arabic compared to Islamic education. While the research of Rahmawati (2017) \& Rosyid (2019) only emphasizes to the discussion on the historical aspects of Pegon's Arab development. This is certainly different from the research that the authors focus on Islamic education. The results of this research are expected to provide implications to educational practitioners to build a concept of education based on local culture, especially based on Arabic Pegon Letters. Furthermore, Hasanah (2016) reported that the implications of learning of book Al-Jurummiyyah with the Arabic pursuits Pegon implicates positively on the skills of khat (writing), the ability to summarize the Arab Pegon with a special mark, knowing the meaning of the each-word and its position. Different point of view on the current research, because the leads to the Arabic language only while the authors lead to more methods and strategies in the broader learning. While, other studies, Wika (2017) was more to the preservation of Javanese script and Pegon script. This study did not lead to the learning process. Solekhah (2017) also reported that the implementation of Weton (intensive learning) makes easier to learn Arabic, al-Quran-Hadith and fiqh. Exercise thoroughness and skill in utilizing the five senses and help memorize the Arabic vocabulary unconsciously.

\section{ACKNOWLEDGMENTS}

The researchers would like to thank to the Ministry of Research, Technology, and Higher Education of the Republic of Indonesia for the financial sopport of the research project. Sincere thanks are addressed to the LPPM Institut Tekhnologi Telkom Purwokerto for other kinds of support. The researchers would like to express sincere gratitude to Mr. Ahyadi and the Ustadz and students of Madrasah Diniyah Al-Barokah who helped researcher to do the research.

\section{AUTHOR CONTRIBUTION STATEMENTS}

The author had participated in the research and approved the final version of the manuscript.

\section{REFERENCES}

Aguilar, G. K., Campbell, H. A., Stanley, M., \& Taylor, E. (2017). Communicating mixed messages about religion through internet memes. Information, Communication \& Society, 20(10), 1498-1520. https:// doi.org/10.1080/1369118X.2016.1229004 
Affan, M., \& Thohir, A. (2020). Studying Religion Through the Internet among Millennial Muslims: Causes and Consequences. FIKRAH, 8(1). http:/ / dx.doi.org/10.21043/fikrah.v8i1.7103

Aisyiah, U. (2016). Revitalisasi Madrasah Untuk Menghadapi Tantangan Globalisasi. Tarbiyatuna, 7(1), 94-102.. Google Scholar

Alimi, M. Y. (2019). Theorizing Internet, Religion and Post Truth: an Article Review. Komunitas: International Journal Of Indonesian Society And Culture, 11(2). https:/ / doi.org/10.15294/komunitas.v11i2.21860

Ahyadi, R. (2019, 11 September). The Result Interview, Teacher, at Madrasah Diniyah.

Bukhory, U. (2015). Menakar Subordinasi Khazanah Lokal (Studi Atas Tingkat Pemahaman Mahasiswa STAIN Pamekasan Alumni Pondok Pesantren terhadap tulisan Pegon). OKARA: Jurnal Bahasa dan Sastra, 9(1), 35-54.. http:/ / dx.doi.org/10.19105/ojbs.v9i1.579.

Chase-Dunn, C., \& Lerro, B. (2016). Social change: Globalization from the Stone Age to the present. Routledge. Google Scholar

Fahmi, I. (2019). Lokalitas kitab tafsīr al-ibrīz karya kh. Bisri mustofa. Islamika inside: Jurnal Keislaman Dan Humaniora, 5(Juni), 96-119. https:// doi.org/https:/ / doi.org/10.35719/islamikainside.v5i1.36.

Fikri, I. (2014). Aksara Pegon: studi tentang simbol perlawanan Islam di Jawa pada abad XVIII-XIX.. Google Scholar

Fikri, I. (2014). Aksara Pegon: studi tentang simbol perlawanan Islam di Jawa pada abad XVIII-XIX. Google Scholar

Gusmian, I. (2015). Bahasa Dan Aksara Dalam Penulisan Tafsir Al-Quran Di Indonesia Era Awal Abad 20 M. Mutawatir: Jurnal Keilmuan Tafsir Hadis, $5(2)$,

223-247. https://doi.org/https:/ / doi.org/10.15642/mutawatir.2015.5.2.223-247.

Hasanah, F. (2016). Problem Pengajaran Menulis Arab Pegon di Madrasah Diniyah Takmiliyah Awwaliyah (MDTA) (Doctoral dissertation, Univesitas Pendidikan Indonesia).. Google Scholar

Hizbullah, N., Suryaningsih, I., \& Mardiah, Z. (2019). Manuskrip Arab Di Nusantara Dalam Tinjauan Linguistik Korpus. Arabi: Journal of Arabic Studies, 4(1), 65-74. http:/ / dx.doi.org/10.24865/ajas.v4i1.145.

Inayatusshalihah, I. (2017). Aksara Jawi dalam Naskah Sarana Walio. Buletin AlTuras, 23(1), 21-36. http:/ / http/ /dx.doi.org/10.15408/al-turas.v23i1.4794.

Irfan, A. (2017). Local Wisdom dalam Pemikiran Kyai Sholeh Darat: Telaah Terhadap Kitab Fiqh Majmu'at al- Shari'ah al-Kafiyah li al-'awam. Ulul Albab: Jurnal Studi Dan Penelitian Hukum Islam, 1(1), 88-109. https:// doi.org/http:/ / dx.doi.org/10.30659/jua.v1i1.2224.

Izzah, F. N., \& Hidayat, N. (2013). Nilai-Nilai Pendidikan Karakter Alam Kitab Al-Akhlaq Lil Banln Jilid I Karyaal-Ustaz'Umar Binahmad Baraja'dan Relevansinya bagi Siswa MI. Al-Bidayah: Jurnal Pendidikan Dasar Islam, 5(1). Google Scholar 
Karim, M. L. (2018). Strategi pembelajaran kitab Al-Akhlaq Lil Banin dalam pembinaan akhlaq santri di Madrasah Diniyah Nurul Islam Karangbesuki Kota Malang (Doctoral dissertation, Universitas Islam Negeri Maulana Malik Ibrahim). Google Scholar

Kitamura, M., \& Takahashi, T. (2020). Changes to the Corporate Philosophy in Response to Corporate Globalization: A Case Study of Globalization in Olympus. In Cultural Translation of Management Philosophy in Asian Companies (pp. 47-68). Springer, Singapore. https://doi.org/10.1007/978981-15-0241-5_4.

Kulsum, Ummu. (2015). Hubungan Kajian Kitab Mabadi' AlFiqhiyyah dengan Pemahaman Santri Tentang Ibadah Shalat Maktubah di Pondok Pesantren Putri Salafiyah Sa'idiyah Arosbaya Bangkalan. Skripsi. Surabaya: UIN Sunan Ampel Surabaya. Google Scholar

Loeb, S., Dynarski, S., McFarland, D., Morris, P., Reardon, S., \& Reber, S. (2017). Descriptive Analysis in Education: A Guide for Researchers. NCEE 20174023. National Center for Education Evaluation and Regional Assistance. Google Schoolar

Lubis, Z., \& Anggraeni, D. (2018). Paradigma Pendidikan Agama Islam di Era Globalisasi Menuju Pendidik Profesional. Jurnal Studi Al-Qur'an, 15(1), 133-153. https:// doi.org/10.21009/JSQ.015.1.07

Mahfudz, S., et al (2018). Kitâbah 'Arab Pegon Khashâishuhâ wa Ishâmâtuhâ fî Tathwîr Ta'lîm al-Lughah al-'Arabiyyah bi Indûnîsiyyâ. Arabiyat: Jurnal Pendidikan Bahasa Arab dan Kebahasaaraban, 5(2), 314-335. https:/ / doi.org/10.15408/a.v5i2.7446.

McClure, P. K. (2017). Tinkering with technology and religion in the digital age: The effects of Internet use on religious belief, behavior, and belonging. Journal for the Scientific Study of Religion, 56(3), 481-497. Google Scholar

Mohamad, A. (2012). Kitab Hidayah Al-Sibyan, Karangan Abu Abdullah Husein Bin Muhammad Nasir Bin Muhammad Thayyib Al-Mas' udi Al-Banjari: Kajian Tahqiq dan Analisis (Doctoral dissertation, Universiti Utara Malaysia).. Google Scholar

Moser, A., \& Korstjens, I. (2018). Series: Practical guidance to qualitative research. Part 3: Sampling, data collection and analysis. European Journal of General Practice, 24(1), 9-18.

Munip, A. (2016). Tracing the History of the Arabic- Javanese Language Translation Books in Nusantara Islamic Education. Jurnal Pendidikan Islam, I(Juni), 43-68. https:/ / doi.org/10.14421/jpi.2016.51.43-67.

Murtadlo, M. (2015). Three Writers of Arabic Texts in Yogyakarta. Heritage of Nusantara: International Journal of Religious Literature and Heritage (eJournal), 3(1), 107-128. http:/ / dx.doi.org/10.31291/hn.v3i1.22.

Mustaqim, A. (2017). The Epistemology of Javanese Qur'anic Exegesis: A Study of Șāliḥ Darat's Fayḍ al-Raḥmān. Al-Jami'ah: Journal of Islamic Studies, 55(2), 357-390. https:/ / doi.org/10.14421/ajis.2017.552.357-390

Ningsih, A. S. R. (2017). Implemntasi pengajian weton (Bandongan) dalam meningkatkan kemampuan menulis arab pegon bagi santri putri kelas I (Pengajian 
weton) di pondok pesantren Darul Huda mayak tonatan Ponorogo tahun ajaran 2016/2017 (Doctoral dissertation, IAIN Ponorogo). Observasi. (2019). Catatan Observasi. Google Scholar

O'Dwyer, L. M., \& Bernauer, J. A. (2013). Quantitative Research for the Qualitative Researcher. SAGE Publications. Google Schoolar.

Payne, M., \& Askeland, G. A. (2016). Globalization and international social work: Postmodern change and challenge. Routledge. Google Scholar

Pudjiastuti, T. (2009). Tulisan Pegon Wujud Identitas Islam-Jawa Tinjauan atas Bentuk dan Fungsinya. SUHUF Jurnal Pengkajian Al-Qur'an dan Budaya, 2(2), 271-284. https:// doi.org/10.22548/shf.v2i2.92

Rahmawati, S. (2015). Ajaran Islam dalam Naskah-Naskah Singir Koleksi Fsui Sebagai Bentuk Persinggungan Budaya Islam-Jawa: Kajian Intertekstualitas. Buletin Al-Turas, 21(2), 243-254. https:// doi.org/10.15408/ bat.v21i2.3840.

Rohkmad, A. (2011). Telaah Karakteristik Tafsir Arab-Pegon Al-Ibriz. Analisa: Journal of Social Science and Religion, 18(1), 27-38. Google Scholar

Rohmah. (2019, 22 September). The Result Interview, Ustadzah, at Madrasah Diniyah.

Rosidi, H. Pendidikan akhlak dalam kitab al-akhlak lil banin jild I (Bachelor's thesis, Fakultas Ilmu Tarbiyah dan Keguruan UIN Syarif Hidayatullah Jakarta). Google Scholar

Rosyid, M. (2019). Gerakan pegon era kolonial hingga era digital: studi kasus di madrasah ibtidaiyah darul ulum ngembalrejo kudus. Auladuna: Jurnal $\begin{array}{llll}\text { Pendidikan Dasar } & \text { Islam, }\end{array}$ https:// doi.org/10.24252/auladuna.v6i1a8.2019.

Salamah. (2019, 22 September). The Result Interview, Ustadzah, at Madrasah Diniyah.

Samidi. (2015). Fikih Kontemporer Bahasa Lokal (Studi Kitab al-Hikmah Karya KH. Ahmad Syakir Lasem), Jurnal SmaRT Vol. 1 No. 2.

Siyoto, S., \& Sodik, M. A. (2015). Dasar metodologi penelitian. Literasi Media Publishing. Google Scholar

Suradi, A. (2017). Globalisasi Dan Respon Pendidikan Agama Islam Di Sekolah. Jurnal Mudarrisuna: Media Kajian Pendidikan Agama Islam, 7(2), 247-266. https:// doi.org/10.22373/jm.v7i2.2364.

Suradi, Ahmad. (2018). The Challenges of Education Based on Multicultural in National Local Culture Conservation in Globalization Era. Cendekia: Jurnal Kependidikan Dan Kemasyarakatan, 16(1), 103-124. https:// doi.org/10.21154/cendekia.v16i1.1156.

Wahyudi, T. (2017). Peran Pendidikan Islam Dalam Membangun World View Muslim. Cendekia, 15(2), 319-340. https:// doi.org/10.21154/cendekia.v15i2.1053

Yakin, A. U. (2017). The Transliteration and Translation of the Leiden Manuscript Cod. Or. 5626 on the Sijill of the Qadi of Banten 1754-1756 CE. Heritage of Nusantara: International Journal of Religious Literature and Heritage 
Islamic Education Based on Arabic Pegon Letters in Madrasah Diniyah Al Barokah Watuagung Tambak Banyumas

(e-Journal), 5(1), 23-76. http://dx.doi.org/10.31291/hn.v5i1.188.

Yusuf, A. M. (2016). Metode penelitian kuantitatif, kualitatif E penelitian gabungan.

Prenada Media.. Google Scholar

\section{Copyright Holder :}

(C) ‘Ulyan, M., Budiyanti, N., \& Nugraha., S. (2020)

First Publication Right :

(C) Jurnal Iqra' : Kajian Ilmu Pendidikan

This article is under:

(ㅇ)(1) (2) 